\title{
WEALTH MANAGEMENT UNTUK PENSIUN YANG SEJAHTERA
}

\author{
Peter Garlans Sina \\ Universitas PGRI NTT, Indonesia \\ Email: petersina83@gmail.com
}

\begin{abstract}
Abstrak: Wealth Management untuk Pensiun yang Sejahtera. Pensiun yang sejahtera menjadi impian semua orang. Oleh sebab itu, untuk mewujudkan pensiun yang sejahtera membutuhkan manajemen kekayaan yang benar. Hasil analisis menemukan bahwa manajemen kekayaan yang benar mampu meningkatkan peluang mengalami pensiun yang sejahtera. Salah satu cara yang dapat diaplikasikan adalah melalui mengelola arus kas dengan benar. Oleh sebab itu, pada bagian akhir diberikan cara yang dapat ditempuh untuk mengelola arus kas dengan benar.
\end{abstract}

Kata kunci: manajemen kekayaan, pensiun, kesejahteraan

\begin{abstract}
Wealth Management for a Prosperous Retirement. Everybody expects a prosperous retirement. Therefore, a suitable wealth management is necessary. The results of the analysis found that the appropriate wealth management is able to increase the opportunities for having a prosperous retirement. A cash flow management is one alternative that can be applied. This paper discusses some approaches to manage a cash flow appropriately.
\end{abstract}

Keywords: wealth management, retired, prosperity

\section{PENDAHULUAN}

Setiap tahun terjadi peningkatan orang jumlah menjadi tua berbagai negara. Survei Biro Sensus Amerika Serikat dalam laporannya tentang data demografi kependudukan internasional menyebutkan bahwa di negara terjadi peningkatan sangat signifikan. Angka kenaikan jumlah paling tinggi di dunia. Dalam kurun waktu antara tahun 1990 hingga 2025, diperkirakan jumlah lanjut usia di Indonesia meningkat 414\% (Suara Merdeka, Senin, 24 Juni 2002). Karena kondisi kehidupan dan perawatan cenderung lebih baik, terdapat kecenderungan peningkatan harapan hidup (Hutapea, 2011).

Lanjut, peningkatan kuantitas lanjut usia belum dapat tentu diikuti dengan meningkatnya kualitas kondisi hidup yang menunjang juga amat hidup. Di Indonesia, kualitas lansia dianggap rendah. Hal ini dapat dilihat dari beberapa indikator antara lain adalah banyaknya lansia yang memiliki ketergantungan kuat pada anak atau keluarga lain, selain kurang produktif. Dari segi pendidikan, ditemukan bahwa secara umum lansia berpendidikan rendah. Rendahnya tingkat pendidikan ini berkorelasi positif dan signifikan dengan buruknya kondisi sosial, ekonomi, derajat kesehatan, dan kemandirian.

Eliana (2003) menegaskan melalui penjelasan walaupun reaksi seseorang terhadap masa pensiun bisa berbeda-beda, tetapi dampak yang paling nyata dalam kehidupan sehari-hari adalah berkurangnya jumlah pendapatan keluarga. Di Indonesia, 
khususnya pensiunan Pegawai Negeri Sipil kondisi keuangan lebih menyedihkan. Data yang diperoleh dari Kompas, 2001 bahkan ada pensiunan golongan I yang menerima rapel kenaikan pensiunan dari bulan Januari sampai dengan Juli 2001 hanya sebesar Rp700,00 (tujuh ratus rupiah saja). Artinya kenaikan yang diterimanya hanya sebesar Rp100,00 (seratus rupiah) per bulannya.

Sebagai seorang kepala keluarga tentunya hal ini bisa menimbulkan stress kepada seluruh keluarga, dalam hal ini istri dan anak. Terlebih jika anak belum bekerja bahkan masih kuliah, sementara istri pun tidak bekerja. Selama ini yang menjadi patokan untuk memasuki masa pensiun adalah faktor usia di mana pekerja dianggap mulai kurang produktif. Di negara barat, seseorang baru memasuki masa pensiun jika ia berusia 65 tahun. Ketika seseorang memasuki masa tersebut secara psikologis ia sudah masuk pada kategori dewasa akhir atau yang lebih dikenal dengan istilah manula. Artinya dari segi produktivitas kerja sudah menurun, dan dari tugas perkembangan pun mereka telah dipersiapkan untuk menikmati kehidupan mereka.

Sementara itu, Abikusumo menambahkan bahwa dalam waktu 15 tahun mendatang, jumlah penduduk lanjut usia 60 tahun ke atas menjadi dua kali jumlah saat ini yakni dari 18 juta jiwa tahun 2005 menjadi hampir 30 juta jiwa tahun 2020. Dan dalam waktu 10 tahun mendatang, jumlah penduduk lanjut usia akan menyamai atau bahkan kemungkinan besar melebihi jumlah penduduk balita. Umur harapan hidup manusia Indonesia akan meningkat dari 68 tahun (2004) menjadi 71 tahun (2020), di mana perempuan lanjut usia akan berusia di atas rata-rata dibandingkan lanjut usia lakilaki.(1) Pada saat ini terdapat 8 propinsi di Indonesia dengan penduduk berstruktur tua (aged structured) dengan proporsi penduduk berusia 60 tahun ke atas lebih dari 7\%. Kedelapan propinsi tersebut adalah DI Yogyakarta (12,48\%), Jawa Timur (9,36\%), Jawa Tengah (9,26\%), Bali (8,77\%), Sumatera Barat (8,08\%), Sulawesi Utara (7,64\%), Jawa Barat (7,09\%), dan Sulawesi Selatan (6,98\%).

Hendratno menegaskan lagi bahwa memasuki masa pensiun memiliki beberapa masalah yang perlu dicari solusinya yaitu bukan hanya masalah keuangan tetapi juga Non Finansial. Kedua-duanya penting dan dapat mempengaruhi kehidupan pada saat pensiun. Karena terjadi Perubahan: Sebelum pensiun adalah pimpinan yang selalu memerintah, mengatur, dan dilayani, bahkan pegawai biasa yang puluhan tahun melakukan aktivitas, tapi saat pensiun sangat berbeda, sehingga timbul perasaan tidak berguna atau juga terjadi post power syndrome, ditambah dengan perasaan kesepian, ketika putra/putrinya menikah dan pindah rumah, bahkan teman teman seangkatannya satu demi satu tidak ketemu lagi. Penurunan pisik dan kesehatan, faktor usia menyebabkan penurunan fungsi-fungsi organ sehingga membutuhkan perawatan dokter atau rumah sakit. Apalagi jika terkena penyakit macam-macam, jika tidak ditunjang dengan kondisi keuangan untuk perawatan, maka kondisinya semakin memburuk. Dengan demikian, berpijak pada berbagai ulasan sebelumnya maka tujuan dari penelitian ini yaitu menggunakan wealth management sebagai salah satu solusi untuk menciptakan pensiun yang sejahtera. 


\section{PEMBAHASAN}

Pensiun hanya sebatas berhenti dari pekerjaan formal dan rutin pada perusahaan milik orang lain atau atasan anda, bukan berhenti berusaha dan bekerja pada bidang atau kegiatan lain. Dengan ungkapan lain, masa pensiun adalah masa bebas menjadi tuan atas diri sendiri, mengisi hidup yang selama ini terlewatkan (Astuti, 2010). Sumber lain, Turner dan Helms (1991) dalam Hakim (2007) menjelaskan pensiun sebagai suatu akhir dari tugas suatu pekerjaan formal dan awal dari suatu peran baru dalam kehidupan, di antaranya berupa harapan perilaku selanjutnya dan bagaimana melakukan mendefinisi ulang (redefine) atas diri (self).

Definisi lainnya dari pensiun Putra (2006) adalah penghargaan terhadap jasa-jasa pegawai yang telah diberikan bagi kehidupan perusahaan tempat ia bekerja. Bagi pegawai, pensiun mempunyai arti sangat tinggi, yaitu sebagai sumber penghasilan pada waktu ia sudah tidak mampu lagi bekerja sebagaimana biasa, karena usia lanjut, cacat jasmani atau karena hal lain. Pensiun juga bersifat sebagai daya tarik bagi setiap pencari kesempatan kerja sehingga menimbulkan minat dan keinginannya untuk bekerja pada perusahaan yang memberi pensiun.

Berpijak pada beberapa definisi sebelumnya, dalam penelitian ini menggunakan definisi menurut Astuti (2010) disebabkan berkaitan dengan siklus hidup sehingga bagaimana mengantisipasi situasi yang tidak diinginkan perlu dilakukan dengan rencana yang cermat. Menurut Supramoko (1991) sebagaimana dilansir oleh Aulia (2012), dalam serangkaian makalah yang ditulisnya pada tahun 1950-an, Franco
Modigliani dan kolaboratornya Albert Ando dan Richard Brumberg menggunakan model perilaku konsumen Fisher untuk mempelajari fungsi konsumsi. Salah satu tujuan mereka adalah memecahkan teka-teki konsumsi, yaitu, menjelaskan adanya bukti yang saling bertentangan ketika fungsi konsumsi Keynes dimasukkan ke dalam data.

Menurut model Firsher, konsumsi bergantung pada pendapatan seumur hidup seseorang. Modigliani menekankan bahwa pendapatan bervariasi secara sistematis selama kehidupan seseorang dan tabungan membuat konsumen dapat mengalihkan pendapatan dari masa hidupnya ketika pendapatan tinggi ke masa hidup ketika pendapatan rendah. Interprestasi perilaku konsumsi ini mendasari hipotesis daur hidup (life-cycle hypothesis). Oleh sebab itu, teori dengan hipotesis siklus hidup dikemukakan oleh Franco Modigliani. Franco Modigliani menerangkan bahwa "pola pengeluaran konsumsi masyarakat mendasarkan kepada kenyataan bahwa pola penerimaan dan pola pengeluaran konsumsi seseorang pada umumnya dipengaruhi oleh masa dalam siklus hidupnya". Karena orang cenderung menerima penghasilan atau pendapatan yang rendah pada usia muda, tinggi pada usia menengah dan rendah pada usia tua, maka rasio tabungan akan berfluktuasi sejalan dengan perkembangan umur mereka yaitu orang muda akan mempunyai tabungan negatif (dissaving), orang berumur menengah menabung dan membayar kembali pinjaman pada masa muda mereka, dan orang usia tua akan mengambil tabungan yang dibuatnya di masa usia menengah. 
Selanjutnya Modigliani menganggap penting peranan kekayaan (assets) sebagai penentu tingkah laku konsumsi. Konsumsi akan meningkat apabila terjadi kenaikan nilai kekayaan seperti karena adanya inflasi maka nilai rumah dan tanah meningkat, karena adanya kenaikan harga surat-surat berharga, atau karena peningkatan dalam jumlah uang beredar. Sesungguhnya dalam kenyataan orang menumpuk kekayaan sepanjang hidup mereka, dan tidak hanya orang yang sudah pensiun saja. Apabila terjadi kenaikan dalam nilai kekayaan, maka konsumsi akan meningkat atau dapat dipertahankan lebih lama. Akhirnya hipotesis siklus kehidupan ini akan berarti menekan hasrat konsumsi, menekan koefisien pengganda, dan melindungi perekonomian dari perubahanperubahan yang tidak diharapkan, seperti perubahan dalam investasi, ekspor, maupun pengeluaran-pengeluaran lain.

Salah satu alasan penting bahwa pendapatan bervariasi selama kehidupan seseorang adalah masa pensiun. Kebanyakan orang akan merencanakan berhenti bekerja pada usia kira kira 65 tahun, dan mereka akan berekspektasi bahwa penghasilan mereka akan turun ketika pension. Tetapi mereka tidak ingin standar kehidupannya, mengalami penurunan besar, sebagaimana diukur dengan konsumsi mereka. Untuk mempertahankan konsumsi setelah berhenti bekerja, orang-orang harus menabung selama masa kerja.

Berkaitan dengan siklus hidup manusia tersebut, mendukung ulasannya Hendratmo bahwa demi mencapai pensiun yang sejahtera memerlukan persiapan keuangan yang memadai yang mana apabila dikaitkan dengan penelitian ini merupakan wealth management yang tepat sehingga walaupun sudah pensiun, dapat mengurangi kesulitan keuangan sebagai dampak tidak bekerja lagi. Peran wealth management ini merupakan langkah logis untuk akumulasi aset keuangan seperti yang dijelaskan oleh Pompian (2006) bahwa orang yang melaksanakan wealth management dengan tepat akan lebih mungkin sejahtera daripada yang tidak melakukannya. Karena bermodalkan wealth management yang baik maka arus kas masuk lebih mungkin dipertahankan dan bahkan dapat diperbesar.

Widiastuti (2009) menjelaskan bahwa wealth management mulai populer dua tahun belakangan ini. jasa wealth management muncul awal tahun 2000, ketika bank asing yang beroperasi di Indonesia menawarkan jasa wealth management, namun sebenarnya wealth management adalah ilmu keuangan yang lebih tua dari manajemen risiko. Pemicu wealth management dirintis oleh private banker pada awal berdirinya pusat keuangan internasional seperti London, Amsterdam, Paris pada abad 17 dan 18. Selanjutnya, wealth management merupakan investasi berkelanjutan dari seorang yang ahli yang mana meliputi perencanaan keuangan dan jasa keuangan. Perencanaan keuangan sebagai rencana mengelola pendapatan ditambah mengelola gaya hidup.

\section{Mengelola Pendapatan}

Mengelola pendapatan dapat dijelaskan menurut My Family Accounting (2007) melalui penjelasan bahwa mengelola rencana keuangan pada prinsip operasionalnya secara umum hampir selalu sama dengan pengelolaan keuangan di 


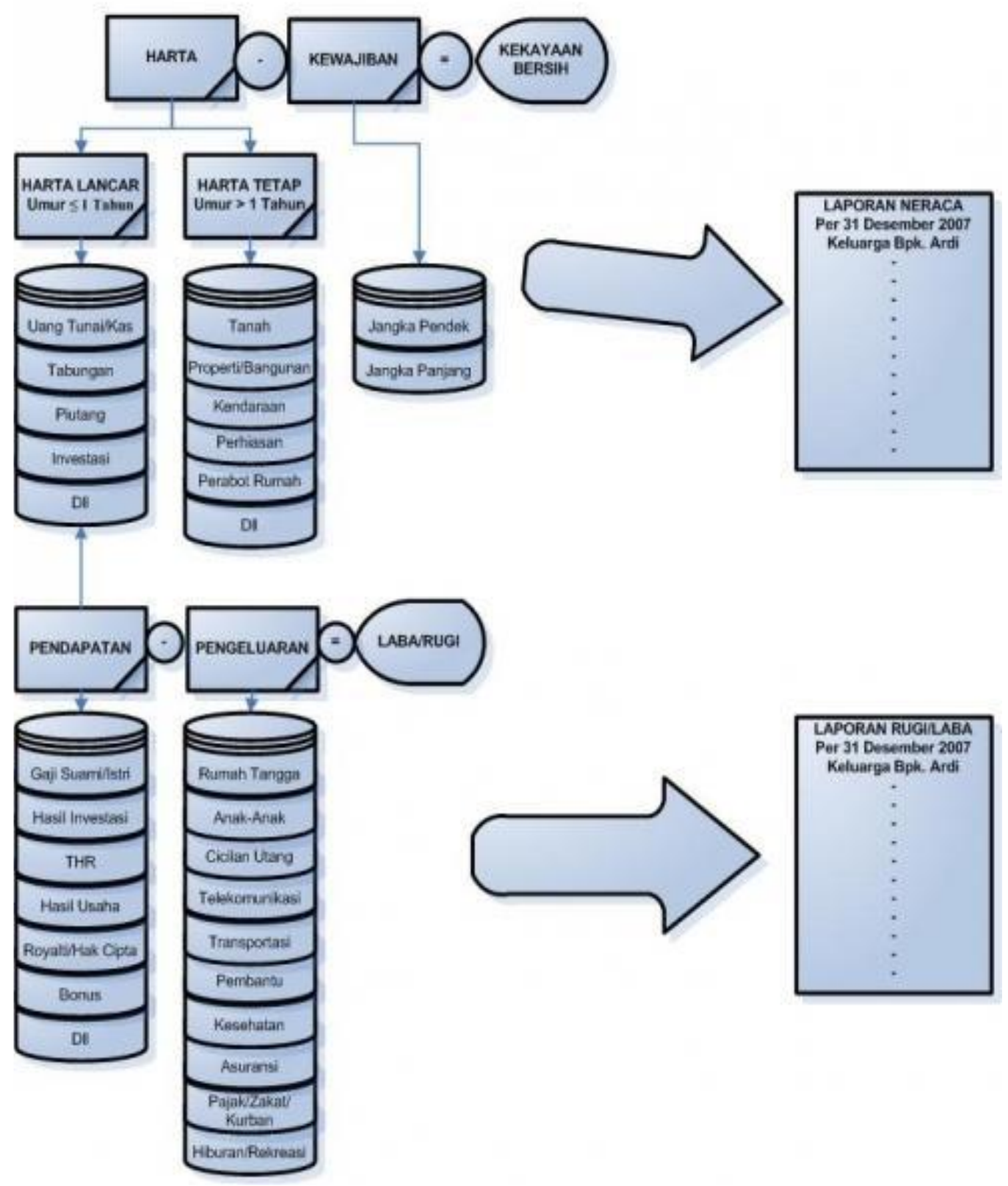

Gambar 1. Diagram Laporan Kekayaan Dan Laba/Rugi Manajemen Keuangan Keluarga

perusahaan misalnya aktivitas-aktivitas pencatatan uang kas yang masuk dan keluar, mengumpulkan bukti-bukti transaksi, membuat anggaran pendapatan dan belanja, mengelola hutang/piutang, laporan kekayaan atau neraca dan laba/rugi di akhir periode. Ini berarti konsep manajemen keuangan keluarga pada dasarnya sama dengan manajemen keuangan perusahaan (Gambar 1).
Selanjutnya dijelaskan bahwa pengetahuan akan cashflow wajib diketahui agar keuangan keluarga tidak kacau balau dan terpantau. Ada sebuah ungkapan yang cukup menarik "tidak peduli keuangan Anda sedang defisit, yang penting Anda tahu kemana mengalirnya uang tersebut". Oleh karena itu pengetahuan siklus dana suatu keluarga sangat penting (Gambar 2).

Dari diagram cashflow manajemen keuangan keluarga di atas terdapat dua arus 


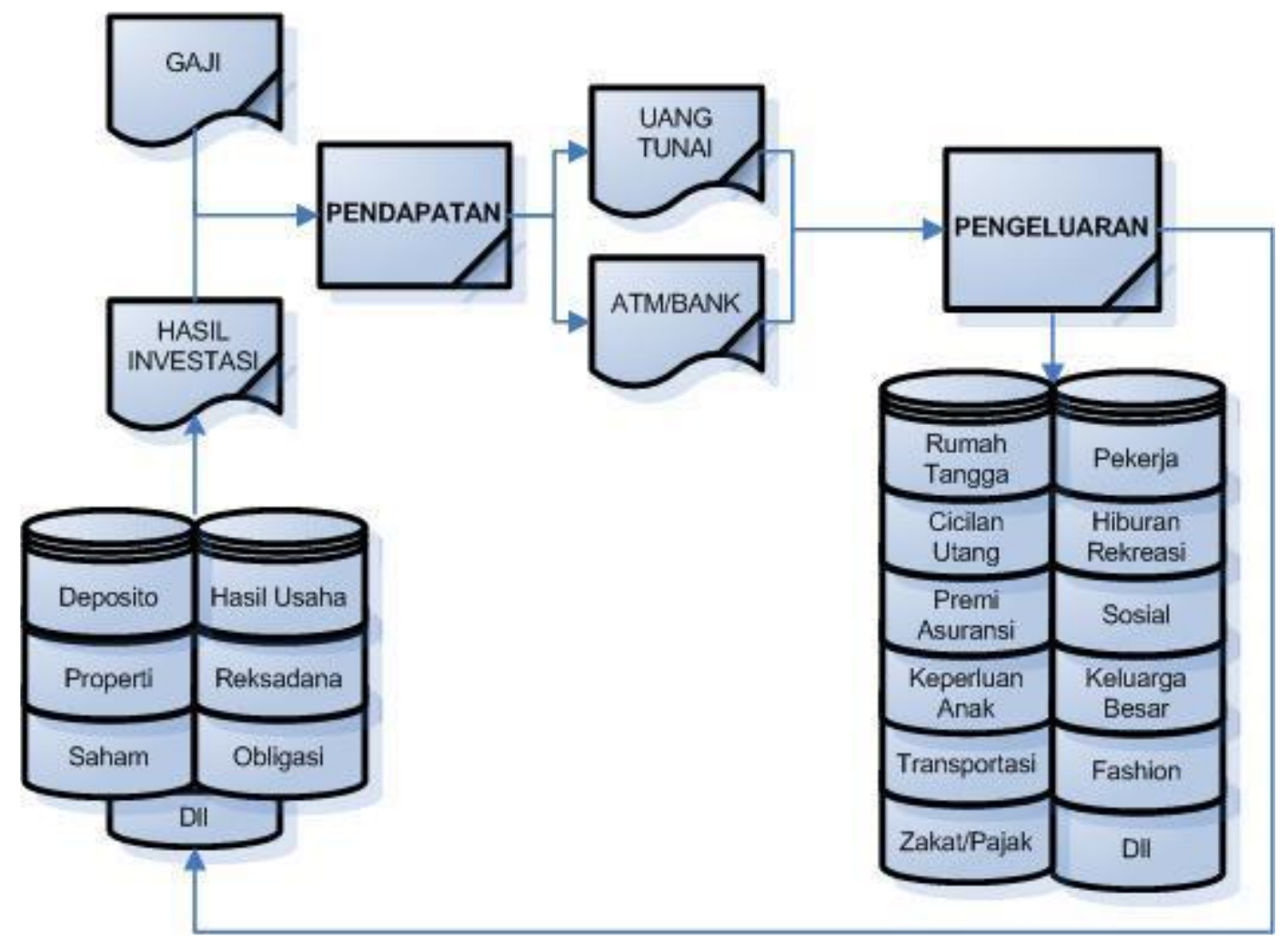

Gambar 2. Cashflow Manajemen Keuangan Keluarga

dana yaitu pendapatan dan pengeluaran. Pendapatan (income) adalah kegiatan yang bertujuan memasukkan uang/harta. Biasanya pendapatan dapat diperoleh dari dua aktivitas, yaitu Gaji dan Investasi. Gaji diperoleh dari status kita sebagai pegawai, karyawan, professional, konsultan. Dalam sebuah keluarga gaji ini bisa diperoleh oleh suami dan istri yang bekerja. Hasil Investasi diperoleh dari aktivitas kita dalam mengembangkan uang/harta dalam berbagai cara.

Ada beberapa cara yang dapat dilakukan berinvestasi yaitu Deposito, Properti, Saham, Hasil Usaha, Reksadana, Obligasi, dan lainlain. Sedangkan pengeluaran berarti seluruh kegiatan yang mengakibatkan uang berkurang. Dari diagram kita bisa melihat banyak sekali kebutuhan akan pengeluaran keluarga, sehingga bila tidak diatur dengan baik akan membuat keuangan keluarga menjadi kacau dan bila sudah kronis dapat menuju ke jurang kebangkrutan. Secara umum sebuah keluarga memiliki beberapa pengeluaran seperti Pengeluaran Rumah Tangga, Cicilan Utang, Premi Asuransi, Pembantu Rumah Tangga, Keperluan Anak, Transportasi, Zakat atau Pajak, Hiburan atau Rekreasi, Kegiatan Sosial, Fashion, dan sebagainya.

Untuk memperkuat mengelola pendapatan yang benar seperti menurut My Family Accounting (2007), maka perlu juga menganalisis pengaturan anggaran menurut Setyorini (2008) sebagai berikut ini. Pertama, catat seluruh sumber pendapatan. Jenis pendapatan pada umumnya jauh lebih sedikit daripada jenis biaya. Jenis pendapatan paling tidak jauh dari: gaji, bonus, tunjangan hari raya, net profit dari 
bisnis personal, sumbangan. Jadi, catat semua pendapatan yang diterima baik yang rutin maupun yang tidak rutin selama sebulan. Kedua, kelompokkan semua pos pengeluaran.

Pintar-pintarlah mengelompokkan pengeluaran. Semakin detil, maka semakin baik.

Ketiga, siapkan kantong-kantong pos pengeluaran. Berdasarkan daftar kelompok pengeluaran yang telah dibuat di atas, maka siapkan kantong-kantong pengeluaran. Sediakan belasan amplop panjang dengan tulisan jenis pos pengeluaran dengan nilainya di setiap amplop. Saat gajian, bagi semua pendapatan yang ada sesuai dengan nilai yang tertera, lalu masukkan ke dalam tempat yang aman. Keempat, lakukan perencanaan keuangan. Buat pos-pos penting dalam amplop yang diberi nama seperti belanja harian, belanja bulanan, kontrak rumah, transpor, uang sekolah serta keperluan rumah yang mencakup listrik, telepon dan air PAM. Tak perlu melakukan penghematan secara drastis. Yang penting Anda harus disiplin dan mematuhi anggaran yang telah dibuat.

Kelima, belanja pada saat diskon. Belanja pada saat diskon dapat menghemat, tetapi hati-hati beli barang atau kebutuhan yang benar-benar dibutuhkan, karena sesuatu dengan diskon belum tentu berhemat atau menabung. Keenam, tabungan sebagai prioritas. Salah satu hal penting yang harus diperhatikan adalah jadikan menabung sebagai prioritas. Mulailah menabung pada awal gajian. Anggaplah menabung sebagai bagian dari setoran rutin yang dilakukan, jika belum sanggup janganlah memaksakan diri menabung dalam jumlah besar, cukup 10 persen dari gaji. Ketujuh, simpan sisa belanja
- biasakan juga memasukkan sisa uang belanja harian ke dalam celengan yang tidak bisa dibuka sesuka hati. Jika celengan sudah terasa berat maka segera pindahkan uang dalam celengan ke tabungan di bank tanpa kartu ATM sehingga tidak dapat diambil sesuka hati.

Ke depan, investasi. Saat tabungan sudah mencapai jumlah tertentu tidak ada salahnya jika menginvestasikan ke dalam bentuk simpanan selain uang (emas, asuransi, dII). Pilih produk gabungan investasi dan asuransi, sehingga jika terjadi sesuatu pada simpanan tersebut, ada asuransi yang menanggungnya. Namun jika kantor sudah menanggung biaya kesehatan, tidak ada salahnya jika berinvestasi dalam bentuk lain, tetapi yang pasti harus bisa memberi manfaat. Kesembilan, bijaksana menggunakan kartu kredit. Simpan kartu kredit di bagian paling tersembunyi di dompet. Walaupun keberadaan kartu ini sering menggoda kebiasaan anda berbelanja, kartu ini tetap berguna di saat-saat darurat seperti ketika harus ke rumah sakit di saat malam buta sementara tidak ada mesin ATM di sekitarnya.

Kesepuluh, siapkan dana pensiun. Mulailah siapkan dana pensiun yang akan berguna kemudian hari. Jika dirasa perlu, ada perencanaan keuangan di beberapa bank atau lembaga keuangan lainnya yang bisa membantu. Kesebelas, bijaksana dalam berutang. Boleh utang tetapi hati-hati. Utang akan selalu mengikuti perubahan kehidupan yang dijalani. Akan tetapi utang yang diambil haruslah sejalan dengan tujuan masa depan yang telah ditentukan, misalnya saja KPR atau utang kepemilikan rumah-motor. Bila sesuai dengan kebutuhan dan tujuan 
keuangan maka hal ini merupakan keputusan bijak. Namun demikian menggali lubang dengan menggunakan kartu kredit untuk memenuhi gaya hidup yang tidak dapat dipenuhi akan sangat berbahaya bagi keuangan keluarga di masa depan. Jadi perhatikan baik-baik sebelum berutang. Terakhir atau kedubelas yaitu evaluasi pengeluaran. Jangan lupa selalu evaluasi pengeluaran setiap bulan. Hal ini bermanfaat untuk menilai pos-pos mana yang terlalu boros.

\section{Gaya Hidup}

Minor dan Mowen (2002) dalam Sundjaja, dkk. (2011) mendefinisikan gaya hidup sebagai: Bagaimana seseorang hidup lebih lanjut dijelaskan bahwa, gaya hidup menunjukkan bagaimana orang hidup, bagaimana orang membelanjakan uangnya dan bagaimana mengalokasikan waktunya. Gaya hidup mencerminkan keseluruhan pribadi yang berinteraksi dengan lingkungan. Jadi gaya hidup adalah pola hidup seseorang yang dinyatakan dalam kegiatan, minat dan pendapatnya dalam membelanjakan uangnya dan bagaimana mengalokasikan waktu.

Sementara itu Ika (2011) menjelaskan, dari sisi gaya hidup, faktor informasi terutama dari para pemasar telah menyentuh aspek psikologis konsumen, hal ini mengakibatkan orang terdorong untuk melakukan pembelian bukan karena kebutuhan tapi faktor keinginan, gengsi, harga diri, mengikuti gaya orang lain dan sebagainya. Dalam beberapa literature/penelitian hal seperti ini dinamakan gejala materialism. Akibat di pos pengeluaran yang seharusnya tidak dianggarkan, dimungkinkan menjadi pengeluaran yang cukup besar dan mendorong anggaran menjadi defisit.

Masih dari sumber yang sama, hasil penelitian Garman dan Irene (1996) perihal perilaku orang dalam mengelola keuangan, teridentifikasi sejumlah 22 kesalahan perilaku. Kesalahan tersebut adalah pengeluaran yang berlebihan, penggunaan kredit yang berlebihan, uang cepat keluar dari simpanan, tidak memiliki dana emergensi, tidak mampu membayar angsuran kredit, penggunaan kartu kredit yang melebihi batas maksimal, tidak memiliki rencana dana pensiun, memiliki hutang yang lebih besar daripada asset yang ada, bahkan sampai dengan kepercayaan bahwa secara rutin akan adanya penghasilan tambahan (bonus) dari perusahaan, sehingga rencanarencana untuk pengeluaran dan membayar hutang telah disiapkan jauh-jauh hari, padahal perusahaan belum tentu merealisasikan bonus tersebut.

Sementara itu, Karvof (2010) mempertegas tentang gaya hidup melalui penjelasannya, ciri khas yang dimiliki orang kaya dan mapan adalah hemat dan bergaya hidup di bawah standar kemampuan. Salah satu poin utamanya adalah meskipun banyak orang kaya yang hidup sederhana, beberapa bahkan amat hemat, tidak berarti pelit. Bertendensi tidak akan mengeluarkan uang untuk sesuatu yang dirasa mewah, berlebihan, dan boros. Namun untuk pengeluaran penting atau pengeluaran mendesak, tak akan pernah ragu melakukannya. Pada kenyataannya, banyak orang kaya yang percaya bahwa memberikan sumbangan merupakan sesuatu yang amat bernilai, dan siap melakukannya untuk 
Tabel 1. Persepsi Kebanyakan Orang Terhadap Orang Kaya Dan Realitas Yang Sebenarnya

\begin{tabular}{|l|l|}
\hline \multicolumn{1}{|c|}{ Persepsi } & \multicolumn{1}{c|}{ Realitas } \\
\hline Memakai mobil kelauran terbaru. & $\begin{array}{l}\text { Kurang dari } 25 \% \text { orang kaya membeli mobil keluaran } \\
\text { terbaru. }\end{array}$ \\
\hline Memakai busana mahal. & $\begin{array}{l}\text { Sekitar } 50 \% \text { atau lebih orang kaya membayar US\$339 } \\
\text { atau kurang untuk busana mahal. }\end{array}$ \\
\hline Tinggal di perumahan elit. & Hanya $20 \%$ orang kaya yang tinggal di perumahan elite. \\
\hline Memakai airloji mahal. & $\begin{array}{l}\text { Sekitar } 50 \% \text { atau lebih orang kaya tidak pernah dalam } \\
\text { hidupnya membayar lebih dari US } \$ 235 \text { untuk sebuah } \\
\text { airloji. }\end{array}$ \\
\hline Memakai sepatu mahal. & $\begin{array}{l}\text { Sekitar } 50 \% \text { atau lebih orang kaya belum pernah } \\
\text { membayar US\$140 atau lebih untuk sepasang sepatu. }\end{array}$ \\
\hline Istri suka belanja. & $\begin{array}{l}\text { Lebih dari } 50 \% \text { istri adalah pengatur dan perencana } \\
\text { anggaran yang cermat. }\end{array}$ \\
\hline Kekayaan diperoleh dari warisan. & $\begin{array}{l}\text { Mayoritas orang kaya tidak pernah menerima warisan } \\
\text { bahkan sebesar US\$1. }\end{array}$ \\
\hline Senang memamerkan status. & Kebanyakan orang kaya tidak suka pamer status. \\
\hline Gaji atau active income besar. & Passive income. \\
\hline Konsumsi berlebihan. & Kekayaan tersebunyi. \\
\hline Ekspresi sosial. & Ekspresi diri. \\
\hline Berfokus pada mereka saya. & Berfokus pada gaya hidup saya. \\
\hline Istri muda. & Istri pertama. \\
\hline Ivy league. & Universitas negeri. \\
\hline Kepala keluarga tua. & Kelaurga paruh baya. \\
\hline Mengejar kekayaan seumur hidup. & $\begin{array}{l}\text { Kekayaan hanya sebagian kecil akibat mengejar } \\
\text { kesenangan. }\end{array}$ \\
\hline
\end{tabular}

orang-orang yang membutuhkan. Hal ini tentunya akan mendorong perbedaan positif, terutama bagi orang-orang yang tidak beruntung dalam suatu komunitas masyarakat, daripada menghabiskan uang untuk membayar perancang mode. Untuk lebih jelasnya tentang gaya hidup orang kaya dapat dilihat di Tabel 1.

Ketika orang banyak mengetahui sifat hemat orang kaya ini, mereka akan cenderung berpikir, mengapa harus bekerja keras jika tak dapat menikmati hasilnya. Jawabannya adalah sebagian besar orang kaya memperoleh kebahagiaan dan kesenangan tidak dengan bersikap boros atau bahkan berlebihan tetap dengan mengerjakan apa yang dicintai atau disukai. Bagi orang kaya, uang hanyalah alat untuk mengukur keberhasilan. Dengan demikian, apabila membelanjakan uang mengakibatkan kenikmatan maka tidak pernah menjadi kaya. Namun jika menghasilkan uang memberikan kesenangan maka kesejahteraan berpeluang dicapai.

\section{Paradigma Baru Pensiun}

Siklus hidup yang dialami dan terus mengalami pertumbuhan yaitu masa belajar menuju lulus sekolah menuju mencari kerja menuju diterima masa percobaan menuju belajar dalam pekerjaan menuju diangkat menjadi pegawai tetap menuju belajar menuju dipromosi menuju naik pangkat menuju belajar di posisi baru menuju naik pangkat menuju akhir pensiun menuju 
Tabel 2. Perbedaan Gaya Pensiun

\begin{tabular}{|l|l|}
\hline \multicolumn{2}{|c|}{ Gaya Pensiun } \\
\hline Tempo Dulu & The Golden Age, Masa Kini \\
\hline Masa penantian menunggu ajal. & Peluang baru mengukir maha karya. \\
\hline Binging mau melakukan apa. & Terarah dan terencana. \\
\hline Layu dan lemas. & Segar dan sehat. \\
\hline Sedih dan sendiri. & $\begin{array}{l}\text { Ceria dan ebrgaul, mengusahakan } \\
\text { persahabatan. }\end{array}$ \\
\hline Tidak punya uang. & Uang tersedia memadai. \\
\hline Meminta karena miskin. & Memberi keberlimpahan. \\
\hline Hidup dan makan berharapa pada orang lain. & Hidup sendiri dan mandiri. \\
\hline Traveling di rumah saja. & Traveling ke berbagai belahan dunia. \\
\hline Negatif dan pesimis. & Produktif dan tetap optimis. \\
\hline Boh, tidak bersemangat dan cepat pikun. & Mau berkreasi dan mau belajar. \\
\hline Diam, malas, dan tidak berkontribusi. & Bergerak, bertumbuh dan berkarya. \\
\hline Pasrah dan menyerah. & Hasrat tinggi dan tetap bergairah. \\
\hline Penampilah lusuh, jorok dan bau. & Bersih, rapi dan wangi. \\
\hline Menajdi beban dan tidak dinginkan. & Tetap bermakna dan selalu dinantikan. \\
\hline Mudah marah dan cerewet. & Tenang, berwibawa, dan menghanyutkan. \\
\hline Lembek dan malas. & Tegap dan berotot. \\
\hline Membutuhkan tongkat untuk berjalan. & Stick golf. \\
\hline Kursi roda. & Mobil bmw. \\
\hline Lemas dan hasrat seks rendah. & Stamina dan hasrat masih terjaga. \\
\hline Tidak tahu diri. & Tua matang dan menjadi teladan. \\
\hline Tuli dan botak. & Semua perkakas terpelihara dengan baik. \\
\hline Jalan dituntun oleh suster. & Tetap antusias. \\
\hline Diberi uang oleh cucu. & Beri akdo pada cucu. \\
\hline Meninggal meningalkan utang. & $\begin{array}{l}\text { Meninggalkan bebersahajaan, kerinduan, nilai- } \\
\text { nilai hidup dan warisan harta dan bisnis. }\end{array}$ \\
\hline & \\
\hline
\end{tabular}

belajar bangun bisnis sendiri menuju menjalankan usaha menuju terus membaca dan belajar, bergerak dan bertumbuh terus menuju berbagi dan mengajar, mentransfer dan berbagai pelajaran dan pengalaman kehidupan kepada generasi muda menuju terus bermakna hingga akhir hayat, bertumbuh dan berkembang di setiap perjalanan waktu kehidupan (Pielor, 2009). (lihat di Tabel 2).

\section{Pensiun dan Sejahtera}

Perbedaan mendasar antara orang kaya dalam menciptakan kekayaan (wealth management) tidak terlepas pada seberapa besar penghasilan yang diperoleh melainkan pada cara mengelola penghasilan yang diterima. Tanpa pengelolaan yang benar, yang ada hanyalah kesulitan keuangan di kemudian hari termasuk masa pensiun. Lanjut bahwa orang kaya mampu membedakan antara aset produktif dan aset konsumtif agar tidak terjebak dalam pengumpulan aset konsumtif. Untuk itu prinsip orang kaya adalah memperoleh penghasilan akan langsung menyisihkannya untuk ditabung sebagai sumber investasi baru setelah itu disisakan untuk dibelanjakan (lihat Gambar 3). Bertendensi untuk berpikir terlebih dahulu sebelum mengeluarkan uang 


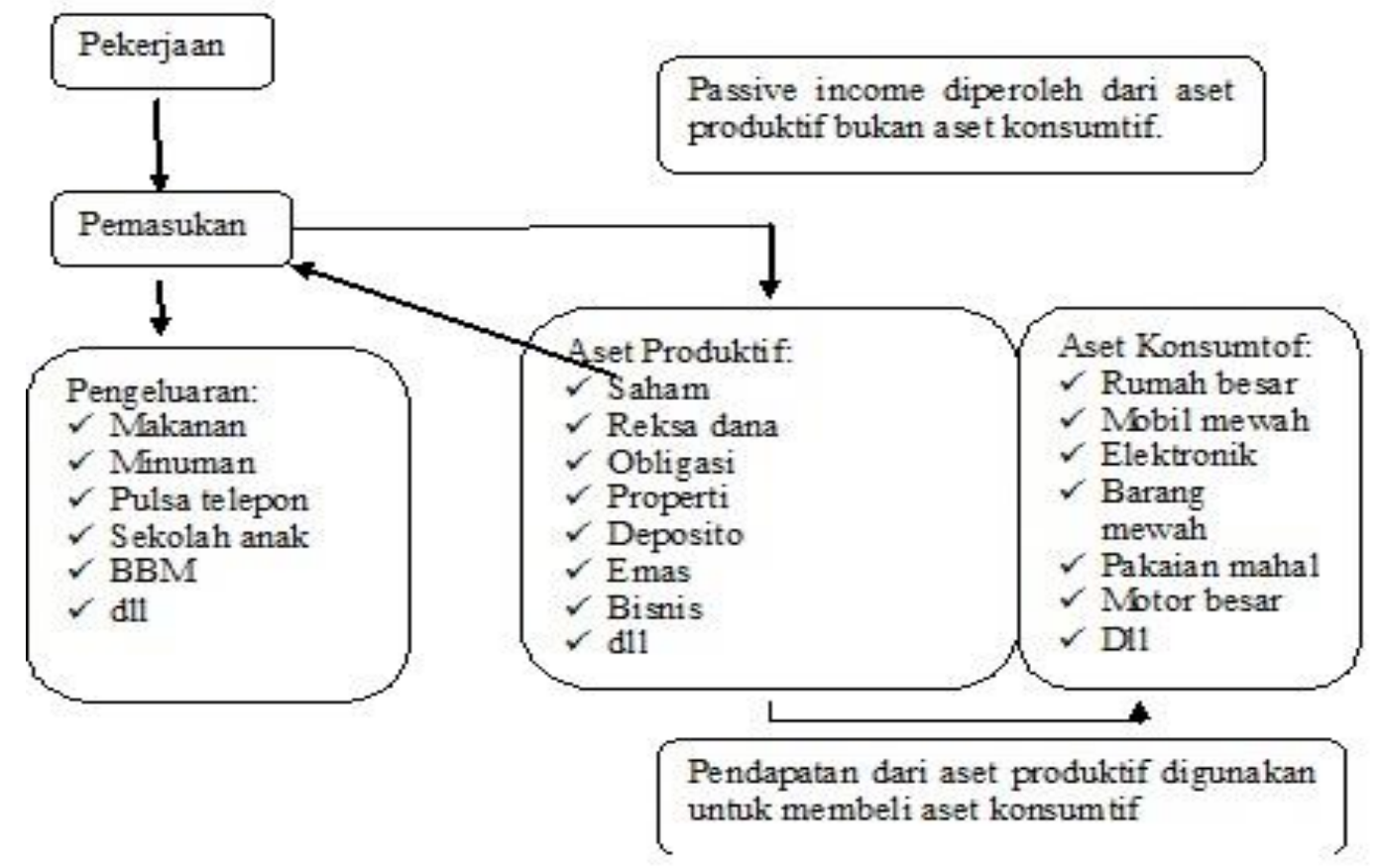

Gambar 3. Pola Arus Kas Orang Kaya yang Pensiun Sejahtera

sehingga berfokus pada akumulasi aset produktif dan hasilnya setelah itu untuk mendanai aset konsumtif dan bukan sebaliknya. Berikut gambar pola arus kas orang kaya dibandingkan dengan kelompok orang miskin dan kelas menengah (Karvof, 2010).

Berbeda halnya dengan kelompok orang miskin yaitu prinsip kelompok orang miskin dalam mengelola keuangan adalah ketika memperoleh penghasilan, langsung dibelanjakan seluruh penghasilan sehingga tidak memperoleh aset produktif. Dengan kata lain, ketika memperoleh penghasilan langsung dibelanjakan untuk kesenangan sehingga tidak akan memiliki keamanan atau kebebasan keuangan.

Tidak jauh berbeda juga dengan kelompok orang menengah terkait prinsip mengelola keuangan yaitu ketika memperoleh penghasilan langsung dibelanjakan untuk konsumsi dan biaya hidup. Sisanya barulah digunakan untuk tabungan dan investasi. Persoalannya kelompok kelas menengah yaitu menggunakan tabungan dalam jumlah besar untuk membiayai aset konsumtif daripada aset produktif. Dari segi keamanan finansial, kelompok ini tidak jauh berbeda dengan kelompok orang miskin karena bergantung pada pekerjaan. Apabila terjadi PHK maka pemasukan akan berkurang sedangkan utang dan biaya hidup terus meningkat sehingga berpeluang mengalami utang yang berlebihan.

Untuk memperkuat aplikasi akumulasi aset keuangan seperti kelompok orang kaya sehingga menambah arus kas masuk, perlu juga memahami siklus keuangan menurut Masassya, memahami berbagai perangkap keuangan menurut Benson yang menyebabkan seseorang tidak mampu mengelola uang dengan benar dan berefek lanjutan pada pensiun yang jauh dari 
sejahtera atau mungkin saja tidak mengalami pensiun yang sejahtera serta Hendratmo. Menurut Masassya (2005) sebagaimana dikutip Ika (2011) akan seperti ini: Usia 20 30 tahun, masa di mana orang mulai membangun landasan keuangan. Pada usia ini seseorang dalam proses meniti karir di bidang apapun dan harus menciptakan financial habit. Langkah tepat yang perlu dilakukan adalah menginvestasikan penghasilan, membeli properti, membeli asuransi (jiwa, kesehatan, dan lain-lain) dan merencanakan dana pensiun.

Usia 30 - 40 tahun, masa ini adalah masa di mana seseorang mulai memantapkan landasan keuangan keluarga dengan langkah-langkah strategis antara lain penumpukan aset dan menambah jumlah financial yang dimiliki. Usia 40 - 50 tahun, usia ini merupakan masa puncak kemandirian yaitu masa menikmati hasil dari investasi yang telah ditanamkan ke beberapa portofolio investasi, menikmati karir atau bisnis. Usia 50 - 60 tahun, usia ini merupakan masa persiapan pensiun, hal yang perlu dilakukan adalah membereskan seluruh hutang/kredit dan tersedianya dana yang cukup untuk pensiun. Usia > 60 tahun, usia di mana seseorang tidak produktif atau melakukan kegiatan sosial non profit dan menikmati pensiun dengan kecukupan dana yang dikumpulkannya dari awal mulai bekerja.

Sedangkan menurut Benson (2004) sebagai berikut: Tidak mengandalkan pada suatu hari nanti yang menyesatkan. Tidak menunda-nunda untuk segera membangun aset dan remanjemen keuangan, tepatnya penerimaan dan pengeluaran per periode waktu tertentu. Tidak menunggu hari hujan sebelum sadar bahwa anda tidak memiliki payung. Masa depan keuangan tidaklah pasti karena sulit untuk memprediksi secara tepat, seperti biaya-biaya tidak terduga atau tidak diantisipasi. Oleh karena itu segeralah membangun aset keuangan. Tidak memberi makan monster.

Tidak melakukan aktivitas belanja barang-barang tanpa ada kontrol dan sadar jika berbelanja menggunakan kartu kredit serta tidak memiliki utang yang berlebihan, sehingga mengganggu keseimbangan pendapatan saat ini dan di masa yang akan datang. Tidak terjebak ke dalam keyakinan bahwa "anda adalah apa yang anda kendarai". Mengeluarkan uang untuk membeli kendaraan dengan mempertimbangkan benefit dan biayanya. Dengan ungkapan lain, menikmati hidup namun tidak melupakan memiliki aset untuk fungsi berjaga-jaga. Tidak bermasalah dengan utang. Berhati-hati membeli barangbarang ataupun jasa menggunakan kartu kredit, sehingga tidak mengalami utang yang berlebihan dan tidak mengalami kesulitan menabung serta investasi. Tidak mengabaikan hubungan antara uang dan tubuh. Menggabungkan kerja cerdas dan kerja keras untuk membangun aset atau menghasilkan uang.

Berhasil memanfaatkan 4 teman yang hebat. Teman pertama, kekuatan prioritas adalah memindahkan sesuatu yang ada di bagian bawah daftar pekerjaan ke atas. Hal itu mengubah tindakan dari dipikir belakangan (suatu hari nanti) menjadi hal yang paling penting (today). Teman kedua, kekuatan tabungan. Teman ketiga, kekuatan berinvestasi di bidang ekuitas. Teman keempat, yaitu kekuatan bunga-berbunga. 
Tidak investasi ekstrem. Terhindar dari jebakan penipuan investasi, yang menjanjikan return ilusi. Tidak mengikuti asuransi ekstrem. Mengikuti asuransi dengan melihat kredibilitas dari perusahaan tersebut, serta memperhatikan syarat-syarat pemberlakuan suatu proteksi. Tidak mengajarkan kesalahan yang sama pada generasi berikutnya.

Terkait Hendratmo, pertama adalah: Mengelola Keuangan Keluarga yang meliputi mengenali peluang penghasilan pasif di masa pensiun, dan strategi untuk mengelolanya, kiat mengatur pengeluaran, memperbanyak aset produktif, menganalisa perubahan keuangan memasuki masa pensiun, menghitung berapa lama uang pensiun dapat bertahan jika tidak melakukan perubahan gaya hidup dan investasi, melakukan penyesuaian gaya hidup dan pola pembelanjaan di masa pensiun, menggali peluang penghasilan pasif dari harta produktif, investasi, dan usaha, mengevaluasi harta yang sudah dimiliki, dan mengubahnya menjadi harta produktif.

Kedua adalah mengelola Uang Pensiun yang meliputi alokasi penggunaan uang pensiun, investasi properti sewaan, membuat alur alokasi uang pensiun, mengalokasikan uang pensiun berdasarkan rencana pensiun masing-masing peserta, mengenali alternatif produk investasi keuangan yang cocok untuk persiapan pensiun, dan pada saat pensiun, mengenali alternatif properti sewaan sebagai penghasilan pasif.

Ketiga adalah wirausaha yang meliputi mengenali karakter keuangan seorang pengusaha, mengenali risiko keuangan seorang pengusaha, mengalokasikan modal usaha dan dana cadangan, mengenali perbedaan pola keuangan sebagai karyawan dan wirausahawan, menghitung dana cadangan yang diperlukan jika memutuskan untuk membuat usaha, menghitung modal usaha yang aman untuk disisihkan dari uang pensiun, mempelajari alternatif sumber permodalan usaha, selain dari uang pensiun.

\section{SIMPULAN}

Setiap manusia memiliki siklus hidup termasuk juga dalam bekerja. Secara normatif setiap manusia pada saat masih berusia produktif untuk akumulasi aset keuangan dan menjadikan hidup bermakna sehingga pada saat pensiun kelak dapat menikmati hidup yang baik, dan bukannya setelah pensiun masih bekerja keras untuk memenuhi hidup. Untuk dapat sejahtera pada saat pensiun dibutuhkan wealth management yang benar sehingga akumulasi aset produktif menjadi kenyataan dan dapat bersukacita pada saat pensiun dan apabila tidak maka kesulitan keuangan atau bahkan kebangkrutan personal dapat saja terjadi.

Melalui hasil analis, dalam penelitian menemukan bahwa semakin bagus wealth management maka semakin bagus pula peluang mengalami pensiun yang sejahtera. dengan kata lain, untuk terhindar dari berbagai masalah keuangan pada saat pensiun maka pilihan mengelola kekayaan menjadi tindakan yang tidak terabaikan. Oleh sebab itu, dalam penelitian ini dibedah panduan konkret untuk mengelola kekayaan sehingga pada saat pensiun akan berbahagia dan bukan mengalami kondisi keuangan sebaliknya yang mana salah satu cara konkretnya adalah melalui manajemen arus kas yang benar untuk akumulasi aset 
keuangan yang berkelanjutan dan dikaitkan dengan siklus hidup keuangan serta memahami berbagai perangkap keuangan yang mengakibatkan dampak buruk pada saat pensiun kelak.

\section{DAFTAR PUSTAKA}

Abikusumo, N. (2005) Model pendekatan bio-psiko-sosial pada masa pensiun. Universa Medicina 24(2), 103-110.

Astuti, S, I. (2010) Pensiun Bukan Akhir Segalanya. http://staff.uny.ac.id/sites/ default/files/tmp/2_PENSIUN\%20BUK AN\%20AKHIR\%20SEGALANYA.pdf

Aulia, S. (2012) Hipotesis Daur-Hidup pada Konsumsi dan Tabungan Kaum Lansia. http://ampundeh.files.wordpress.com/2 012/05/hipotesis-daur-hidup-dankonsumsi-serta-tabungan-padalansia.pdf

Benson, D. (2004) 12 Kesalahan bodoh yang dilakukan orang terhadap uang mereka dan bagaimana cara mengatasinya. Batam: Gospel Press

Eliana, Rika. (2003). Konsep diri Pensiunan. 2003 Digitized by USU digital library

Hakim, S, N. (2007) Perencanaan dan Persiapan Menghadapi Masa Pensiun. Warta, 10(1), $96-109$.

Hendratno. Perencanaan Keuangan Masa Pensiun.

http://hendratno.blog.ittelkom.ac.id/blo g/files/2013/05/Perencanaan-Kug-MasaPensiun.pdf

Hutapea, B. (2011) Emotional Intelegence dan Psychological Well-being pada Manusia Lanjut Usia Anggota Organisasi berbasis Keagamaan di Jakarta. Insan, $13(2)$.
Ika, A. (2011) Personality Traits sebagai Penentu Perencanaan Keuangan Keluarga (Suatu Kajian Pustaka). Ragam Jurnal Pengembangan Humaniora. 11(2), 118-126.

My Family Accounting. (2007) Dasar-Dasar Manajemen Keuangan Keluarga Profesional (1) dan (2). http://myfamilyaccounting.wordpress.co $\mathrm{m} / 2007 / 05 / 14 /$ dasar-dasar-manajemenkeuangan-keluarga-profesional-1/

Karvof, A. (2010) Kaya dengan CEPIL; cara cerdas meraih kekayaan dan keberkatan finansial. Jakarta: Elex media komputindo

Pielor, F. (2009) Jangan Mau Pensiun Berkarat, Melarat \& Sekarat. Jakarta: Elex media komputindo

Pompian, M, M. (2006) Behavioral Finance and Wealth Management. Hoboken, New Jersey: John Wiley \& Sons, Inc.

Putra, I. (2006) Faktor-Faktor Pendorong dan Penghalang Pensiun Dini Pegawai Negeri Sipil (PNS) di Sumatera Barat. Jurnal Demokrasi. 5(1)

Setyorini, D. (2008) Perencanaan Keuangan Rumah Tangga. Disajikan pada tanggal 1 Agustus 2008 pada Penyuluhan Cara Pengaturan Anggaran Keuangan Rumah Tangga bagi Ibu-ibu PKK Dusun Plugon Desa Donomulyo, Kecamatan Nanggulan, Kabupaten Kulon Progo

Sundjaja, R, S. dkk. (2012) Pola Gaya Hidup Dalam Keuangan keluarga (Studi Kasus:Unit Kerja Institusi Pendidikan Swasta di Bandung). Bina Ekonomi Majalah IImiah Fakultas Ekonomi Unpar. 15(2), 1-12.

Widiastuti, P. (2009) Mengenal Wealth Management. http://purwatiningyogya.blogspot.com 